\title{
Celebrations for the 50-Year Anniversary of IFToMM
}

\author{
Marco Ceccarelli ${ }^{1} \cdot$ Tian Huang $^{2} \cdot$ Teresa Zielinska $^{3} \cdot$ Juan Antonio Carretero ${ }^{4} \cdot$ Tadeusz Uhl $^{5}$
}

Published online: 9 September 2019

c) Krishtel eMaging Solutions Private Limited 2019

During the 15th IFToMM World Congress on Mechanism and Machine Science (MMS) in Krakow, Poland on 30 June-4 July 2019, a special opening session has been organized to celebrate the 50-year anniversary of IFToMM with unveiling of a bronze commemorative plaque, Fig. 1.

In the 15th World Congress, 637 participants from 66 countries and regions have been registered and 437 papers have been presented in a dense program with 17 topic sections of the wide domain of MMS and the most relevant to the IFToMM Technical Committees. The Springer Nature in Series Mechanism and Machine Science published proceedings of 15th World Congress proceedings in five volumes, [1].

IFToMM was founded in 1969 during the Second World Congress on Mechanism and Machine Science in Zakopane, Poland with an act, Fig. 2, that was signed on 29th September 1969 by the IFToMM founding fathers, (see Appendix

Marco Ceccarelli

marco.ceccarelli@uniroma2.it

Tian Huang

tianhuang@tju.edu.cn

Teresa Zielinska

teresaz@meil.pw.edu.pl

Juan Antonio Carretero

juan.carretero@unb.ca

Tadeusz Uhl

tuhl@agh.edu.pl

1 Department of Industrial Engineering, University of Rome Tor Vergata, Rome, Italy

2 School of Mechanical Engineering, Tianjin University, Tianjin, China

3 Faculty of Power and Aeronautical Engineering, Warsaw University of Technology, Warsaw, Poland

4 Department of Mechanical Engineering, University of New Brunswick, Fredericton, Canada

5 Department of Robotics and Machine, University of Science and Technology AGH, Kraków, Poland
1), during a special meeting establishing also the first Executive Council, Fig. 3, [2, 3].

A celebration session was planned with the following speeches of the living past IFToMM Presidents to outline the scientific and social aspects of the history of IFToMM:

- IFToMM: Yesterday, Today, and Tomorrow by Prof. Marco Ceccarelli

- The Forming of International and Personal Connections Through IFToMM inspite of a Turbulent World by Prof. Bernard Roth

- The Existential Question of IFToMM in the Twenty-first Century by Prof. Jorge Angeles

- Intersections Between My Career and IFToMM by Prof. Kenneth Waldron

- Let Me Think About The Gap Between IFToMM Globalism And The Economic Globalism by Prof. Yoshihiko Nakamura

In addition, a special set of posters on IFToMM history was exhibited in the Congress hall during the 2019 World Congress near the bronze commemorative plaque, Appendix 2.

At the end of the celebration session, the current IFToMM President, Marco Ceccarelli, and the Chair of the 2019 World Congress, Tadeusz Uhl, revealed the commemorative plaque, Fig. 4, among the enthusiastic applauses of the congress attendees.

In Fig. 5 the living past IFToMM Presidents share their appreciation for the celebration.

Figure 6 shows the Executive Council members serving in years 2016-2019 surrounding the just unveiled plaque with satisfaction for the celebrations that were coordinated with the Congress organizers since the early days of 2016 with many discussions among World Congress 2019 organizers and the IFToMM Executive Council members.

Figure 7 is the group photo of the attendees at the end of the celebration session from more than 600 participants at the Congress coming from 66 countries and regions. 


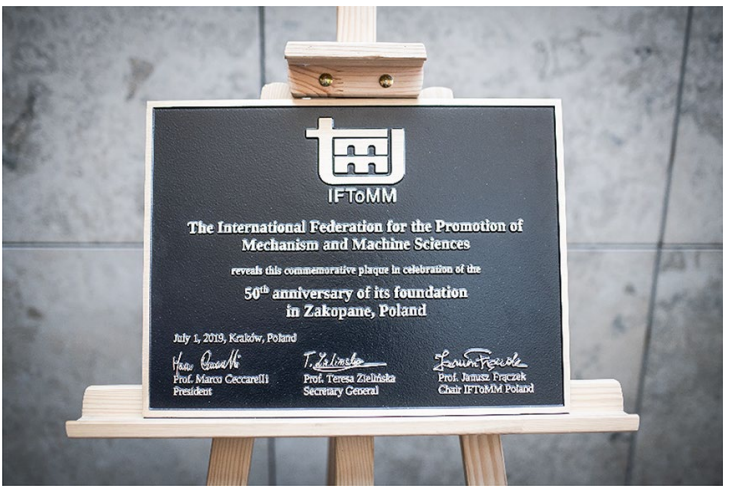

Fig. 1 The bronze commemorative plaque for the 50-year anniversary of IFToMM

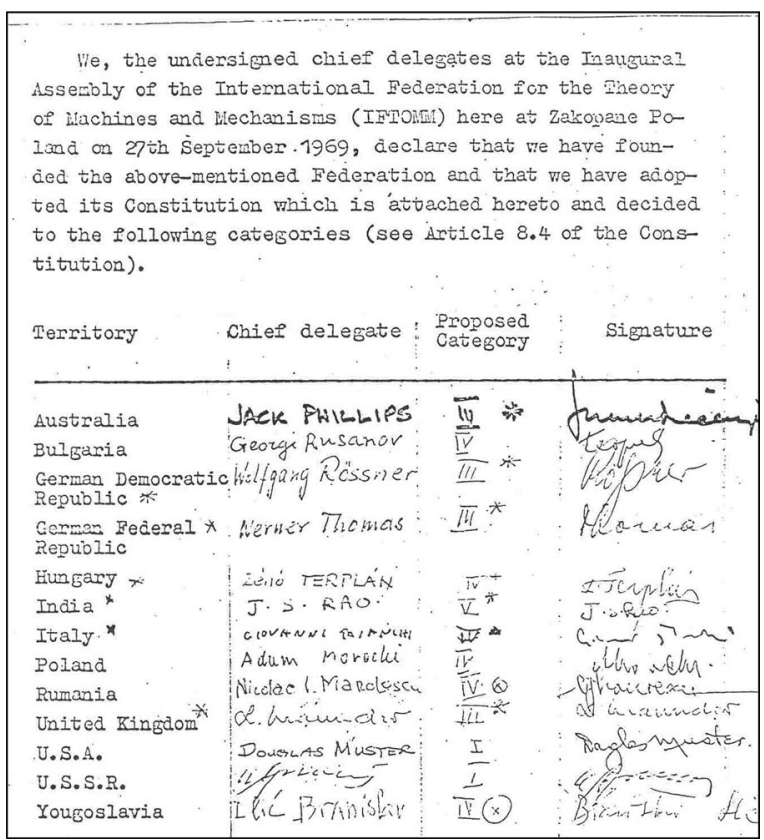

Fig. 2 The founding act of IFToMM

Fig. 3 Announcement of the foundation of IFToMM on 29th September 1969. (Courtesy of IFToMM Archive) in which one can recognize: 1 -Prof. Ivan Ivanovic Artobolevskii (USSR); 2-Prof. Adam Morecki

(Poland); 5-Prof. Nicolae I.

Manolescu (Romania); 6-Prof.

Erskine F. Crossley (USA); 7Prof. Giovanni Bianchi (Italy); 8-Prof. Aron E. Kobrinskii (USSR); 9-Prof. Werner

Thomas (Germany); 10—Prof. Jan Oderfeld (Poland)

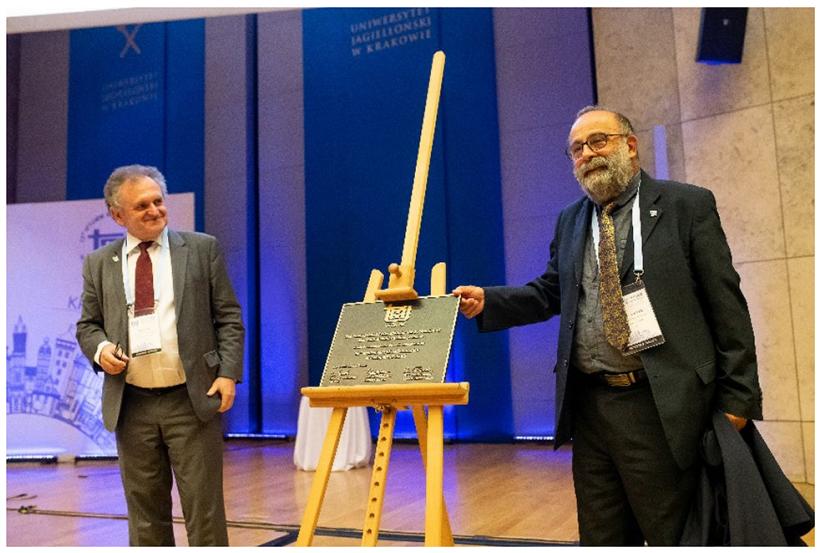

Fig. 4 The reveal act of the bronze commemorative plaque

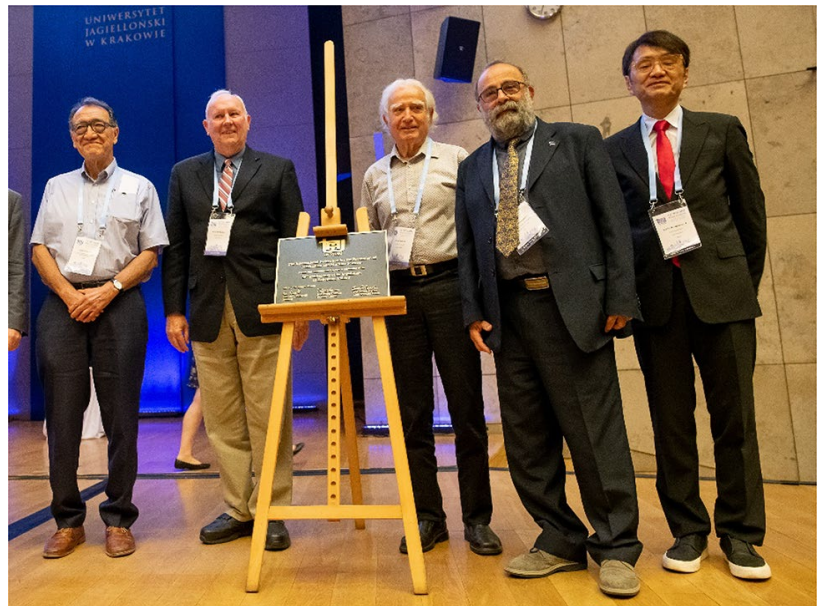

Fig. 5 The living past IFToMM President with the commemorative plaque in exhibition. (from left to right): Prof. Jorge Angeles, Prof. Kenneth Waldron, Prof. Bernard Roth, Prof. Marco Ceccarelli, and Prof. Yoshihiko Nakamura

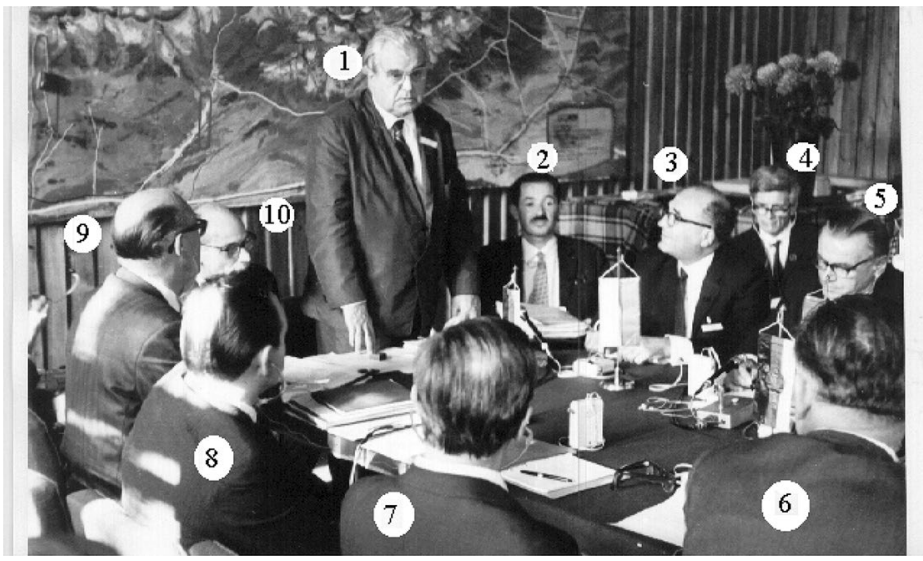




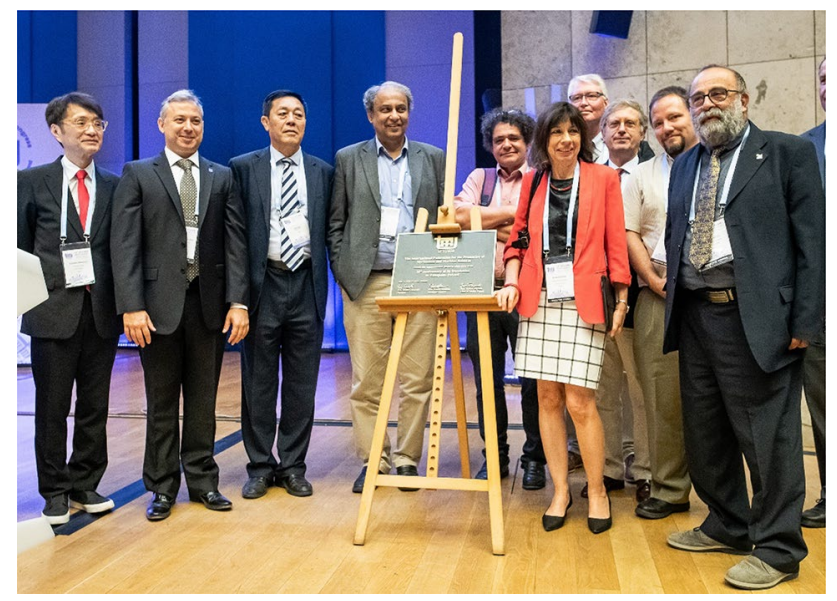

Fig. 6 The members of the current IFToMM Executive Council with the commemorative plaque in exhibition (from left to right): Prof. Yoshihiko Nakamura, Prof. Can Dede, Prof. Tian Huang, Prof. Ashitava Ghosal, Dr. Jean-Pierre Merlet, Prof. Teresa Zielinska, Prof Burkard Corves, Prof. Fernando Viadero, Prof. Juan Antonio Carretero, Prof. Marco Ceccarelli

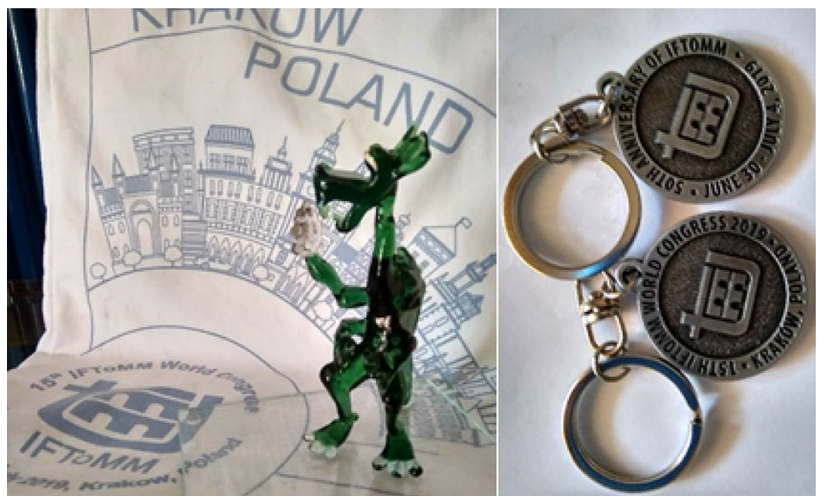

Fig. 8 Gifts at the 2019 IFToMM World Congress as memory of the IFToMM anniversary

The celebration finalized with a wine toast in a familiar frame and will live in the memory of all attendees through the specially designed celebratory congress gift to the attendees, Fig. 8.
Fig. 7 Group photo of the attendees at the celebration of the IFToMM 50-year anniversary

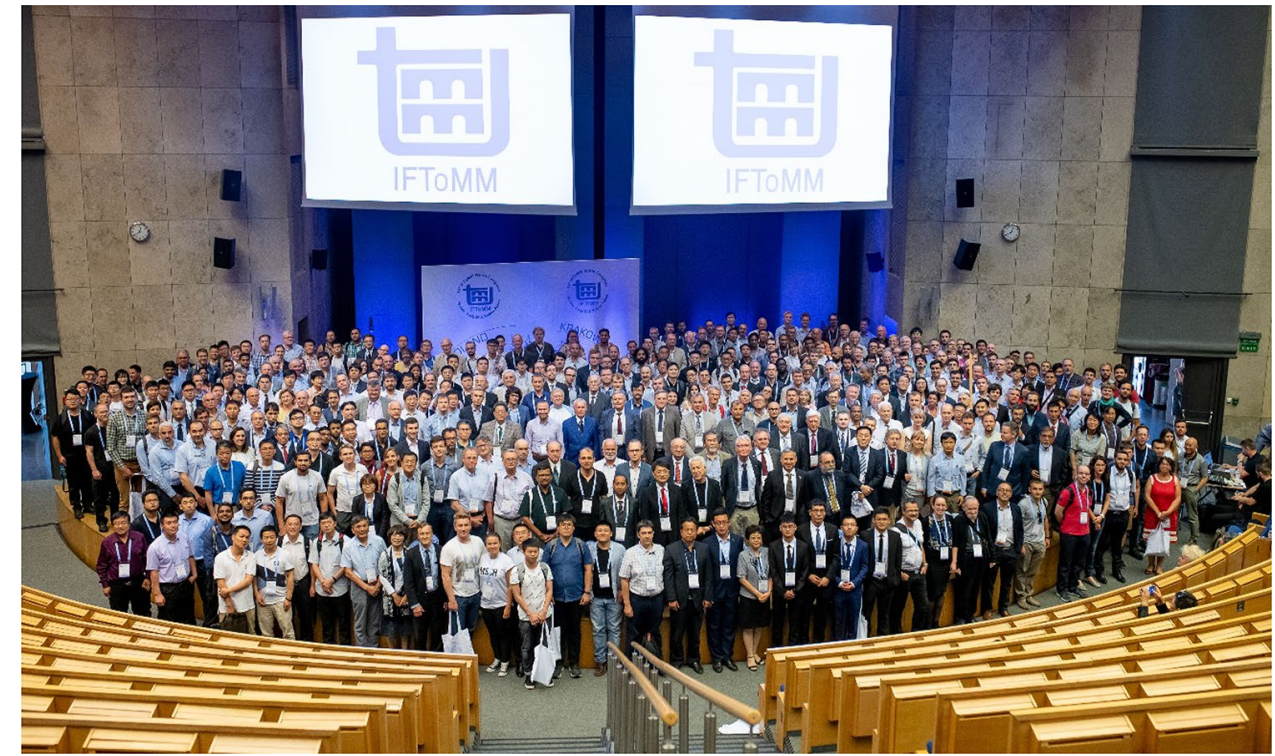




\section{Appendix 1: Poster on the Founding Fathers of IFToMM at 2019 World Congress}

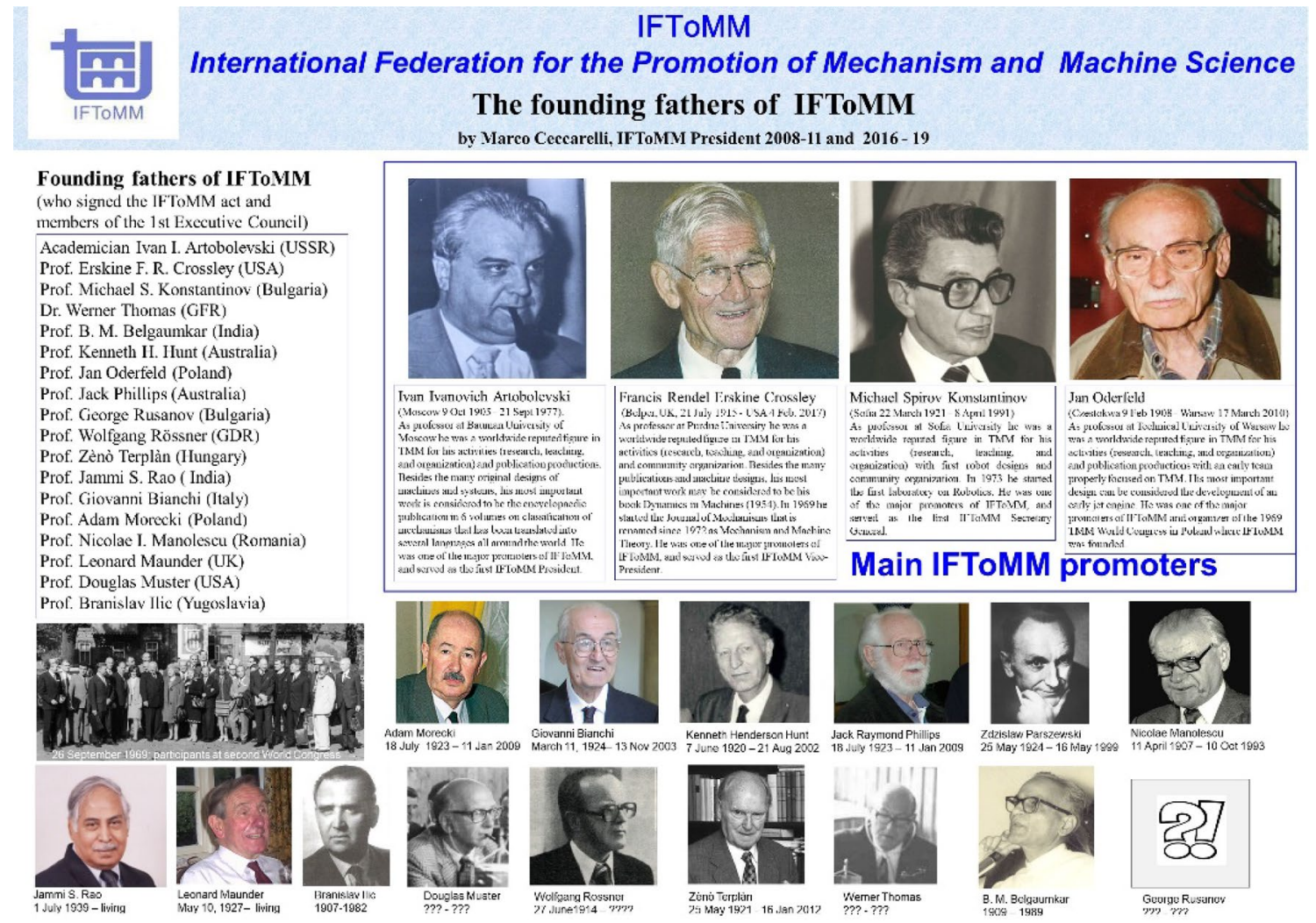

\section{Appendix 2: List of Posters Exhibited During the IFToMM 2019 World Congress in Krakow, Poland}

1. IFToMM officers (from IFToMM webpage)

2. What is IFToMM? (from IFToMM webpage)

3. IFToMM History (from IFToMM webpage)

4. IFToMM Founding Fathers

5. IFToMM Sponsored Conferences

6. IFToMM Awards and Honors

7. Activity of IFToMM Executive Council

8. SIOMMS IFToMM Student Olympiad

9. All WCs

10. WC 1987 in Seville

11. WC 1995 in Milan

12. WC 2004 in Tianjin

13. WC 2007 in Besancon

14. WC 2011 in Guanajuato

15. WC 2015 in Taipei

16. IFToMM Flyer

\section{References}

1. Uhl T (ed) (2019) Advances in mechanism and machine scienceproceedings of the 15th IFToMM world congress on mechanism and machine science, Springer, Cham

2. Ceccarelli M (2015) A short account of History of IFToMM and its role in MMS. Mech Mach Theory 89:75-91. https://doi. org/10.1016/j.mechmachtheory.2014.09.007

3. Angeles J, Bianchi G, Bessonov AP, Maunder L, Morecki A, Roth B (2004) A history of IFToMM, chapter 2. In: Proceedings of HMM2004-the Second IFToMM International Symposium on History of Machines and Mechanisms, Kluwer, Dordrecht, pp $25-125$

Publisher's Note Springer Nature remains neutral with regard to jurisdictional claims in published maps and institutional affiliations. 